\title{
INTRODUCTION In the name of Europe
}

\author{
Sandra Ponzanesi ${ }^{\mathrm{a} *}$ and Bolette B. Blaagaard ${ }^{\mathrm{b} * *}$ \\ ${ }^{a}$ Department of Media and Culture Studies/Graduate Gender Programme, Utrecht University, \\ Utrecht, The Netherlands; ${ }^{b}$ Centre for Law, Justice and Journalism, City University London, \\ London, UK
}

(Received 14 September 2009; final version received 28 May 2010)

\begin{abstract}
Though that [imperial and colonial] history remains marginal and largely unacknowledged, surfacing only in the service of nostalgia and melancholia, it represents a store of unlikely connections and complex interpretative resources. The imperial and colonial past continues to shape political life in the overdeveloped-but-no-longer-imperial countries. (Gilroy, 2004, p. 2)

'Europe' in a sense is a phantom of the past, a name that 'is history' rather than society, political, or economics, since the flow of capitalization, population, communication and political action, cross its territory, invest its cities and workplace, but do not elect it as a permanent of specific site. Europe is not only de-territorialized, but also de-localized, put 'out of itself', and in the end deconstructed. It may be part of an imaginary, but less and less of the real. (Balibar, 2004, p. 10)
\end{abstract}

This special issue approaches feminist, postcolonial and race theory from different cultural, disciplinary and national backgrounds. The contributors engage with the question of what makes Europe postcolonial and how memory, whiteness and religion figure in representations and manifestations of European 'identity' and selfperception.

This intervention is necessary as the notion of Europe is now contested more than ever, both internally (through the proliferation of ethnic, religious, and regional differences) and externally (Europe expanding its boundaries but closing its borders). Is Europe a bulwark, an exclusionary and discriminatory fortress, or the last romantic ideal of a supra-national organization based on ideas of peace, justice and emancipation?

Many people still hold onto the notion that Europe is not simply a continent, a mere geographical space that continually redefines its boundaries and peripheries, but they want to see it as an ideal, the cradle of the Enlightenment and of scientific revolutions, and therefore of Western modernity and democracy. But as Gilroy writes in his epigraph, Europe is not innocent and does not reside beyond the disruptive forces of colonization; and as Benhabib states, the idea of Europe is an illusion instrumentalized to enforce new power dynamics:

*Email: s.ponzanesi@uu.nl; **Email: bolette.blaagaard.1@city.ac.uk 
Contemporary Europe is facing the danger that its moral and political boundaries will be redefined via geographical borders. Geography once again will be used to cover the tracks of complex processes of political and moral inclusion and exclusion ... [Europe] whether as an ideal or illusion, whom does it include and whom does it exclude? After the Cold War who are Europe's 'others'? (Benhabib, 2002, p. 155)

It is for these reasons that the Somali writer Nuruddin Farah accuses the European Union, often invoked as the political synonym for Europe, of being another scapegoat for 'postcolonial responsibility'. He argues that European nations do not want to take responsibility for their hazardous and short-sighted redefinition of national borders and ethnic allocations during colonial times that have brought about the recent mass migrations towards Europe. The European Union is, according to Farah, another empire of a more sophisticated order, which has taken the role of doing away with the imperial responsibilities of countries such as Britain, France, Portugal, the Netherlands and Italy. The people of this new empire are barricading themselves within an empty rhetoric of fear and helplessness. But as Farah (2000) forcefully puts it:

If refugees are a challenge as well as a reproach to our humanity, if refugees are a lament raised, a cry spoken, if refugees are the bastards of the idea of empire, then how can one blame this highly disenfranchised, displaced humanity for all Europe's ills? (p. 55)

Farah addresses the responsibilities of the European Union, because he too has occupied the ambiguous territory of colonization and was forced to see himself as someone else's invention (Farah, 2000). As Graham Huggan writes, refugees and asylum seekers remind us of the limit of cosmopolitanism and of the contradictions of a 'euphoric' globalist worldview which should welcome migrants of every religion and ethnicity into the celebration of a world without borders (Huggan, 2008, p. 245). Conversely, Agamben (1994) states in 'We refugees' that:

If in the system of the nation-state the refugee represents such a disquieting element, it is above all because by breaking up the identity between man and citizen, between nativity and nationality, the refugee throws into crisis the original fiction of sovereignty ... For this reason - that is, inasmuch as the refugee unhinges the old trinity of state/nation/ territory - this apparently marginal figure deserves rather to be considered the central figure of our political history. It would be well not to forget that the first camps in Europe were built as places to control refugees, and that the progression - internment camps, concentration camps, extermination camps - represents a perfectly real filiation. (1994, para. 5)

Following this line of thought, Passerini argues that we should perceive Europe less as a political program and more as an emotional project. The Europe that Passerini envisions is an imagined territory, rather than a self proclaimed and arrogant identity that is a locus for doubt, absences and shortcomings. The latter is an important analysis in order not to forget that Europe is not the cradle of civilization and humanity but the inheritance of many painful and violent connections (from the imperial past to Auschwitz, to the current resurgence of racism). These 'unwelcome' legacies need 'not be forgotten, but dismantled and uprooted' and addressed (Stråth, 2000, pp. 14-15).

In this new revaluation of where Europe is at the moment we should keep in mind that there has been a shift from Eurocentrism into what Philomena Essed has termed 
Europism (Essed, 1995, p. 54) which has become even the more strident after 9/11. Eurocentrism refers to the old discourse of European superiority and domination over the south, through colonial expansion, imperialism and the civilising mission. Europism in contrast, is more introspective and characterized by the defensive discourse of constructing a pure Europe cleansed of foreign and uncivilized elements. Eurocentrism is therefore marked by Europe's movement towards the outside whereas Europism is marked by an inward looking position, and homogenizing process from the inside. Essed sees Fortress Europe as a form of Europism, operating both as an ideology and as a bureaucratic machinery to create legal, economic and political boundaries to protect Europe against the rest of the world, in particular the South. This idea of Western Europe goes well beyond an ideological construction, and is often implemented through a body of legislation whose objective is to close borders against refugees and immigrants.

As Wendy Brown (2008) has debated, the proliferation of borders or the creation of new walls is not resurgent expressions of nation-state sovereignty in late modernity but rather icons of its failure. The epidemic of building walls and strengthening borders is, in fact, testimony to the corrosion of the sovereign state instead of its authority. The borders that determine Europe have become, as Balibar writes, 'uncertain' and, despite the constant refencing of Fortress Europe, are vacillating. However, they are being replaced by multiple, invisible and internal borders that mark new forms of inclusion and exclusion based on linguistic, racial, ethnic and religious divisions. Balibar constructs his argument around what he terms 'European apartheid,' which makes reference to the types of exclusions that are implemented not only at the level of legislation but also as a way in which Europe is constructed as a concept. Balibar maintains that borders have not been eliminated but that there is a multiplication of borders in the form of 'internal borders', a myriad of new invisible borders that are ideological, radicalized and politicized (Balibar, 2003).

Borders are therefore moving from physical (the gate to European territories and citizenship) and symbolic (the myth of Europe and its idea of superiority) to material borders (the marked body of foreigners, immigrants and asylums seekers) which become 'border' figurations (construction of otherness, foreignness, alienness). These embodied borders come to signify a somewhat cohesive category that, pretty much in line with Said's notion of Orientalism, places the 'European subject', i.e. the host, in a position of definition by default. Instead of being the signifier, the European subject becomes the hollow referent, a kind of blind spot that needs the other for his/ her/its self-definition. The European is what the other is not, therefore unmarked by race, ethnicity and religion but in reality implicitly constructed upon the idea of maleness, whiteness, and Christianity.

One of the best lessons of postcolonial thinking was precisely not the analysis of dichotomous relationships but the exploration of intertwinements, contaminations and condition of dependencies that allow for the undermining of the priority of one signifier above the other. Postcolonial cultural theorist, Iain Chambers, presents for example the Mediterranean as the hybrid product of cultural and material flows that resist the rigid mapping of borders and linear notions of progress. Chambers defines a geography without a real East or West, in which the 'Occident' and the 'Orient' are not guideposts but unwanted intrusions (Chambers, 2008). This special issue explores a number of theoretical discussions on the meaning of Europe and proposes 
analyzing some of the deeds committed, both today and in the past, in the name of Europe by foregrounding a postcolonial approach. To read Europe as a postcolonial place does not imply that Europe's imperial past is over, but on the contrary that Europe's idea of self, and of its polity, is still struggling with the continuing hold of colonialist and imperialist attitudes. The objective of this issue is to forefront new forms of interventions by accounting for historical legacies which have been denied, forgotten or silenced, such as the histories of minor and peripheral colonialisms (Nordic colonialisms or Austrian, Spanish and Italian colonialism) and to account for the realities of liminal locations within Europe, such as the Mediterranean and the Eastern border. In postcolonial Europe we also need to take into account the many forms of internal colonialism (such as indigenous groups, Roma people or endangered ethnic minorities) along with the more frequently debated consequences of fluxes resulting from former colonialism and new global dynamics (migrants, refugees and asylum seekers).

This is to circumvent the absence of Europe within postcolonial studies, and to account for minor histories of imperialism (outside the role of the British, French or Dutch empires) as part of the grander ideals of Europe and its hegemonic role. The toolbox of postcolonial theory has, in fact, rarely been used to study the reality of contemporary Europe. This oversight reinforces the colonial assumptions that demarcate postcolonialism as something that concerns the Third World and not the 'center' (i.e. Europe) of colonial discourse. This means that Europe becomes not only a hollow signifier in the postcolonial debate, but also a blind spot, despite once having been the cradle of major colonialism and imperial histories and of having built its claims of modernity, democracy and progress (including the advent of feminism and gender emancipation) in opposition to the realities of the colonialized nations (Barker, 1985). To account for minor histories of postcolonialism means to question the dominance of the Anglo-Saxon paradigm within colonial and postcolonial studies, which re-centers many discourses around London and the former colonial outposts (especially India) as the major axis of investigation. Moreover, the global role that the English language fulfils in academia repositions British history of empire, and Anglo-American scholarship, into a hierarchy that overshadows other imperial histories, often defined as minors - not because of their less nefarious impact - but rather for their marginal position that has placed them in relative oblivion following decolonization (Ponzanesi, 2004). Needless to say, these protracted silences of Europe's many colonial histories are crucial to understanding the era of Postcolonial Europe. As Paul Gilroy (2004) writes:

The modern histories of numerous other European countries [besides Britain],
particularly Belgium, France, Spain, Italy, and The Netherlands, might also be used
to construct equivalent arguments amidst the wreckage of their colonial extensions and
the injustices of their inconsistent responses to immigration. These analyses would be
based upon their obvious difficulties in acknowledging the pain and the gains that were
involved in imperial adventures and upon the problems that have arisen from their
inability to disentangle the disruptive results supposedly produced by an immigrant
presence from the residual but potent effects of lingering but usually unspoken colonial
relationships and imperial fantasies. (Gilroy, 2004, p. 109)

To explore Europe as a postcolonial place and to acknowledge the histories of its many minor empires within is crucial as most of the complex postcolonial dynamics 
are founded in Europe as a result of migration, fluctuation in labor market forces, the rise of fundamentalism, and resurgent racism. Some of these realities are clearly the legacy of European colonial policies, whereas others are dictated by global disjunctions. Europe functions as a 'hinge' between its colonial past and the current globalized world and as a micro-political location where many of the worldwide economic, social and cultural tensions are refracted in particular ways. Therefore, there is urgent need to account for the denial and pluralities of European colonial histories and to investigate how they influence national multicultural policies and what they mean for the definition of Europe in a comparative and international context (Ponzanesi and Merolla, 2005).

Graham Huggan pertinently highlights that the one key area in which older, as well as more recent, colonialist attitudes and prejudices reassert themselves is that of 'race relations'. He argues that race has itself undergone numerous semantic shifts and transformations but despite its obvious centrality to postcolonial concerns it arguably still continues to be an under-theorized term in postcolonial studies (Huggan, 2008, p. 243). Within the new asset of the European Union, racism is no longer to be understood as establishing hierarchies of difference predicated upon fixed biological categories, but, as Balibar writes, it is rather 'racism without race' which turns diversity into immutable difference which makes the coexistence between various cultural groups impossible (Balibar \& Wellerstein, 1991, p. 23). According to this vision, multiculturalism can also be seen as a new legitimated form of racism as the so-called dominant or mainstream groups manage hierarchies of acceptable and unacceptable difference.

It is for these reasons that practices of exclusion in Postcolonial Europe are more insidious than those in the old racist Europe because they substitute old paradigms with new economic and religious ones. Sara Gibson argues, for example, that in the case of the UK, where the cultural and political issue of blackness has been debated since the arrival of postcolonial migrants, 'the body of the asylum seeker or refugee becomes the (un)marked body of strange(r)ness in current debates. This move from the "black" immigrant to the figure of the asylum seeker mirrors the movement from a racism predicated upon biological difference, to a "meta-racism" predicated upon cultural difference, to the current form of "xeno-racism" and "asylophobia", (Gibson, 2006, p. 697). This shift from symbolic differences (referring to racialized bodies and figures) to economic and cultural difference (referring to economic migrants and political refugees) runs parallel to Europe's appropriation and integration of some forms of otherness as its own in its re-branding as multicultural place.

This is why this special issue investigates less explored forms of colonialism along with instances of new racism in order to map out the diversified modes of resistance to them in specific geo-political and historical contexts, while retaining a European comparative approach. The anti-immigration issue is, for example, explored in several papers accounting for how the legacies of specific colonial policies (such as the Habsburgs in Austria, the fascist rule in Eastern Africa or the removed Danish empire) can explain, or at least shed new light onto, the multicultural dilemmas of many European countries whose postcolonial status still needs to be proven. The postcolonial approach is therefore called into creating the connection between past legacies and current multicultural frictions in which the figure of the migrant (and also of the refugee and asylum seeker) becomes iconic for the changing 
configurations of Europe. To address anti-immigration issues means therefore to account for both the laws and regulations as well as for the ideological representations and symbolic order proposed by conflicting actors in Postcolonial Europe.

The essays deal with social and political formations as well as cultural and artistic practices, often focusing on women as the major site of interaction between conflicting loyalties, interests, legacies and rationales (Lutz, 1997). This issue draws from different disciplinary backgrounds and methodological traditions, and the collected essays create space for comparative and cross-disciplinary exchanges.

The first section of this special issue focuses on the submerged colonial legacies of marginal locations in Europe (i.e. Iceland, Denmark, Austria, Italy) and the second section analyzes the representations of migrant voices through different languages, genres and media (literature, cinema, music, art) across Europe.

The first section also focuses on how critical whiteness is developing as an important field to analyze the European context. Critical whiteness presents researchers with as many questions as the rest of the postcolonial field; and it does so while navigating different routes of analysis and uprooting the intricate issues of European postcolonialism. 'Whiteness studies' have come to Europe through American scholars' thorough investigations into the racial matters and debates in the US. However, when transposed into European history, political reality today and cultural memories of identities, nations and territories, the scholarly work done in the US is merely a platform for the re-evaluation of whiteness in terms of the particularities within and of Europe.

European colonial history depicts resemblances and differences from US racial history and politics. These are differences and resemblances that in each case need to be considered if critical whiteness studies are to make any sense in a European context. Being white or not white in Europe draws on discourses surrounding not only diaspora, slavery and segregation (though it does that too), but also religion, ethnicity, migrations and 'scientific' ambitions of phrenology and eugenics, national identities and territorial disputes. Whiteness constructed in the European context was not made up of legal structures, but of fluid structures of power relations, which have shifted throughout time and are still changing. Therefore critical whiteness studies in a European context raises issues of exclusion and inclusion, geographical and ethnic borders, migration and integration and assimilation. Critical whiteness is an aspect of this special issue and is elucidated in Kristin Loftsdóttir's article on the negotiations of white identity within the Icelandic population in a historical analysis that is expanded into a contemporary critique.

The intricate patterns of Nordic colonialism (see Charpentier et al., 2009) allow a country like Iceland to both assume a position as a former colony of Denmark and simultaneously textualize its position into that of a 'white' nation - on the political and genetic side of Britain, France and Belgium in the 'scramble for Africa' producing unique opportunities to explore what 'whiteness' means in a European context and history and what postcolonial Europe may encompass.

Denmark's colonial history spread both in Nordic and southern directions. However, the issue of the Nordic colonies is often neglected or limited to discussions about Viking exploration and the vagueness of citizenship at the time of conquest. Or the issues are discussed in terms of the current financial situation in the colonies and their potential independence from Danish funding and politics. The former southern Danish colonies - Tranquebar, the Gold Coast (Ghana), and the Danish West Indies 
(the current US Virgin Islands) - are dealt with in archaeological and historical terms, and rarely engage with the present political and cultural situation in these places. However, looking at the converging space between journalism and cultural memory, when the past is allowed entry into the present it facilitates a historicized future. In this special issue Bolette B. Blaagaard examines how journalistic practices contribute to the continuous construction of cultural memory. Her article takes as a point of departure the argument that not only major events, but also everyday occurrences that are reported in the news media, help confirm who 'we' are in a given community. The question of 'collective' or 'cultural' memory is explored through journalistic representation and practices. The article addresses the issues of cultural and archival historical representations as they are presented in Danish journalism about historical events taking place in the former colonies of Denmark, the current US Virgin Islands.

The Austrian empire was of a magnitude that many of us have forgotten. In their article, B. Hipfl and D. Gronold argue that the imperial past of Austria has not been excavated and has not become part of public consciousness. This omission prevents Austria from defining itself as a multicultural state in the present. However, the new immigrants and asylum seekers confront Austria with its past and challenge the comfortable and accessible view of the Habsburgian empire as an exemplary case of 'multiculturalism': combining nations, languages and people. The recent fluxes of immigration also renew a sense of loss that occurs in remembrance of the AustroHungarian Empire's glorious past, which loses its aura of nostalgia and touristy folklore.

In their piece on Naples as a porous city, Claudia Buonaiuto and Marie-Hélène Laforest refer not only to the forgotten legacy of Italian colonialism in Eastern Africa but also to the many forms of internal colonization within the nation. Buonaiuto and Laforest analyze the divisions between north and south, the city within the state, the ghettos within the city, and the multiple layers (both historical and geographical) of migrants and migrations claiming an identity within this most spectacularly complex city, which functions as a microcosm that illustrates the intersections between the many global souths of the world and the so-called 'center' (i.e. Europe).

In the second section the contributors specifically focus on how Europe has been revisioned, resignified and remoulded by its so-called strangers: postcolonial migrants, refugees and asylum seekers who see Europe as a transitory zone or as a final destination. This issue illustrates that it is not the outcasts and the ghosts from the underbelly but the strangers within who are now determining not only the configuration of European cities but also the renewed understanding of political citizenship, cosmopolitanism and human rights. This vision challenges ongoing or previous definitions of 'Europeanness' that has never been a static entity but an articulation of imaginations and belongings that needs to be unraveled and redrawn in its multiple layers of meanings, convergences and emotions.

The strangers within are part of the European discursive construction, rich in connotations and ambiguities, and as such operate in the name of Europe. These strangers are often pre-assigned, spoken for and relegated to the realm of victimhood in order to be entitled to the right of entrance, sojourn and protection in Europe. The dual politics of disenfranchisement while offering supposed 'solidarity', articulates an ambivalence that has been amply elaborated by Derrida in his notion of 
hospitality. This is textually, visually and aurally articulated in several recent European artworks, novels, songs and films which magnify the condition of the migrants as mirroring the violent benevolence of their hosts. From their perspective, before departure Europe is often a mirage, a paradise to be reached which is in stark contrast to the hostile reality of arrival, of borders that have been created within the nation between 'us' and 'them' that relegate 'them' to a uniform, homogenous history and geographical otherness.

In her article 'Europe in motion' Sandra Ponzanesi focuses on the contested notion of the (new) Europe from the vantage point of migrant cinema by analyzing how the politics of encounter is represented in three recent European migrant films: Yasmin, Unveiled and The Unknown Woman. These visual and ideological commentaries participate in the redefinition or abolition of the notion of Europe by presenting the representations of the strangers within. They do so not by depicting from original and unexpected positions but by highlighting the transformation of the 'European subject' through the politics of encounter. It explores how cinematic language offers alternative modalities of representation and subjectification in relation to migration, gender and identity.

Lourdes López Ropero and Alejandra Moreno Álvarez examine how the notion of conviviality takes shape in recent literary, cinematic and artistic productions, by paying attention to the dominant paradigm of British multiculturalism (through the work of Yinka Shonibare, Andrea Levy, Monica Ali) and how it connects and relates to other forms of emerging multiculturalism within Europe such as in the case of Spain (Lucía Etxebarría).

In her article 'Rented spaces', Manuela Coppola discusses how Italy recently acknowledged the presence of 'second generation' migrants, people of non-Italian origin who are still striving for recognition and who are increasingly gaining access to practices of self-representation. She analyzes the trend of migrant literature in Italy as a controversial site of self-representation, and suggests that women writers gain visibility through access to publication, but they still occupy ambiguous spaces of exotic objectification and limiting definitions. She refers to the concept of 'rented spaces' as a metaphor to investigate the politics of cohabitation in postcolonial Europe which can render the multiple signifiers of social, cultural, and linguistic practices.

Esther Sánchez-Pardo's article sketches the complexities of Spain's postcolonial reality and explores how the historically homogeneous emigrating country is transforming into a destination for members of several diasporas, many with their own legacies of colonialism and racism. Due to its European Union status and growing presence in the world economy, Spain is participating in a global phenomenon in which immigrants, asylum seekers, and refugees are looking towards the new Europe as an impenetrable fortress instead of a site of multicultural interaction. By analyzing the work of black African migrant writers who are residents of Spain (Inongo-vi-Makomé, Susan Akono and Donato Ndongo) her article explores the ways in which the self is reconstructed in diasporic situations through the various underpinnings and fragmentations of the migration experiences that are represented in narrative processes.

In her article on 'Dubbing di diaspora', Sonia Sabelli analyzes gender representations in reggae music in postcolonial Europe in the context of the processes of the global consumption of reggae music and the international 
appropriation - by white musicians - of a musical genre that historically had a black identity. She explores how reggae performers and audiences responded to the colonial strategy of legitimizing images that perpetuated European colonial governance through the exercise of command and subordination, whether identifying black liberation with virility, and male control of women's bodies, and therefore perpetuating sexist images and concepts and homophobic attitudes, or re-visioning their struggle for freedom in forms that do not support or perpetuate phallocentrism and patriarchal control.

As a coda to the issue we have included an original interview with Vron Ware, an important theorist of critical whiteness studies who explains the transitions from the dominant US paradigm to past and current European specificities and creates links and references to the issues addressed in Postcolonial Europe.

Postcolonial Europe is an ongoing project that requires continuous fresh perspectives and an account of untold or forgotten stories, told from both established institutional positions and more marginal ones. By collecting the efforts, voices and expertise of scholars, artists and independent thinkers throughout Europe, this issue is an attempt to map some of the possible routes for unthinking Europe in a global era.

\section{Acknowledgements}

We are particularly grateful to Rosi Braidotti and Vron Ware for their critical feedback and helpful suggestions on earlier drafts of these articles. We would also like to thank the anonymous reviewers for their comments and useful remarks.

This special issue is the output of the 'Postcolonial Europe' working group, operating under Athena3, the EU sponsored Advanced Thematic Network of Women's Studies in Europe (http://www.athena3.org/). We are particularly grateful to Athena and its coordination for having provided the basis for regular annual meetings across Europe and for having financed the special workshop held in Utrecht in May 2008 in which Vron Ware participated as an invited guest. Another output of the working group is the online course 'Postcolonial Europe: Gender, Ethnicity and Migration' which can be found on www.postcolonialeurope.net

\section{References}

Agamben, G. (1994). We refugees (M. Rocke, Trans.). Symposium, 49, 114-119. Retrieved September 14, 2009, from http://www.egs.edu/faculty/agamben/agamben-we-refugees.html

Balibar, E. (2003). We, the people of Europe? Reflections on transnational citizenship. Princeton, NJ: Princeton University Press.

Balibar, E. (2004, November). Europe as borderland. Paper presented at the Alexander van Humboldt lecture in human geography, University of Nijmegen, The Netherlands. Retrieved September 14, 2009, from http://socgeo.ruhosting.nl/colloquium/Europe $\% 20$ as $\%$ 20Borderland.pdf

Balibar, E., \& Wellerstein, I. (1991). Race, nation, class: Ambiguous identities. London: Verso. Barker, F. (Ed.) (1985). Europe and its others: Proceedings of the Essex Conference on the Sociology of Literature, July 1984. Colchester: University of Essex.

Benhabib, S. (2002). The claim of culture. Equality and diversity in the global era. Princeton, NJ: Princeton University Press.

Brown, W. (2008, April). Porous sovereignty, walled democracy. Paper presented at the Katz Distinguished Lecture in the humanities, University of Washington, USA. Retrieved September 14, 2009, from http://dpts.washington.edu/uwch/katz/20072008/wendy_ brown.html 
Chambers, I. (2008). Mediterranean crossings: The politics of an interrupted modernity. Durham, NC: Duke University Press.

Charpentier, S., Keskinen, S., Tuori, S., \& Mulinari, D. (Eds.) (2009). Complying with colonialism: Gender, race and ethnicity in the Nordic region. London: Ashgate.

Essed, P. (1995). Gender, migration and cross-ethnic coalition building. In H. Lutz, A. Phoenix \& N. Yuval-Davis (Eds.), Crossfires: Nationalism, racism and gender in Europe (pp. 48-64). London: Pluto.

Farah, N. (2000). Yesterday, tomorrow: Voices from the Somali diaspora. London and New York, NY: Cassell Academic.

Gibson, S. (2006). 'The hotel business is about strangers'. Border politics and hospitable spaces in Stephen Frears' Dirty pretty things. Third Text, 20, 693-701.

Gilroy, P. (2004). After empire: Melancholia or convivial culture? London and New York, NY: Routledge.

Huggan, G. (2008). Perspectives on postcolonial Europe. Journal of Postcolonial Writing, 44, $241-249$

Lutz, H. (1997). The limits of Europeanness: Immigrant women in fortress Europe. Feminist Review, 57, 93-111.

Passerini, L. (2000). The last identification: Why some of us would like to call ourselves Europeans and what we mean by this. In B. Stråth (Ed.), Europe and the other and Europe as the other (pp. 45-65). Brussels: Peter Lang.

Ponzanesi, S. (2004). Paradoxes of postcolonial culture: Contemporary women writings of the Indian and Afro-Italian diaspora. Albany, NY: Suny Press.

Ponzanesi, S., \& Daniela M. (Eds.) (2005). Migrant cartographies: New cultural and literary spaces in postcolonial Europe. Lanham, MD: Lexington.

Stråth, B. (Ed.) (2000). Europe and the other and Europe as the other. Brussels: Peter Lang. 